\title{
SOCIO-ENVIRONMENTAL FACTORS INFLUENCING PREFERENCES FOR TYPHOID FEVER TREATMENT AMONG SECONDARY SCHOOL STUDENTS IN IKENNE, SOUTH-WEST, NIGERIA
}

\section{Edejoro Oghoghoviano Ozakpo ${ }^{1 *}$ and Babasola Oluseyi Olugasa ${ }^{2}$}

Department of Public Health, School of Public \& Allied Health, Babcock University, IlishanRemo, Ogun State, Nigeria

1*Correspondence Author Email: ozakpoedejoro@ gmail.com; Tel no: +2347062973852

${ }^{2}$ Email Address: bolugasa@yahoo.com

Cite this article:

Edejoro O.O., Babasola O.O. (2021), Socio-environmental Factors Influencing Preferences for Typhoid Fever Treatment Among Secondary School Students in Ikenne, South-West, Nigeria. International Journal of Public Health and Pharmacology 1(1), 31-42. DOI: $10.52589 /$ IJPHP6ISGJRWV.

\section{Manuscript History}

Received: 10 April 2021

Accepted: 31 April 2021

Published: 12 June 2021

Copyright $(\odot 2020$ The Author(s). This is an Open Access article distributed under the terms of Creative Commons Attribution-NonCommercialNoDerivatives 4.0 International (CC BY-NC-ND 4.0), which permits anyone to share, use, reproduce and redistribute in any medium, provided the original author and source are credited.
ABSTRACT: Typhoid fever was estimated to produce 17.8 million cases each year among low-and-middle-income countries of the world. This study aimed to identify the socio-environmental factors that influence care-seeking preferences for typhoid fever treatment among students of Secondary Schools. The study adopted a cross-sectional design guided by behavioural theories that employed quantitative methods of data collection. A multistage sampling technique was used to select five (5) schools from five wards in the study area. A total of 422 students were recruited for this study but only 417 questionnaires were correctly and completely analysed. A self-administered questionnaire was used for data collection and the data was analysed using, descriptive statistics, chart, mean, standard deviation and inferential statistics of correlation, and multiple regression. The respondents' ages ranged from 10-19 years with a mean of $15.3 \pm$ 1.7 years. Results demonstrated that the socio-environmental factors that influence the respondents' health-seeking behaviour for typhoid treatment were the decision of parents on the type of treatment they can receive as well as the cost of the treatment The study further revealed that of the respondents who have had typhoid fever in their lifetime, less than half sought treatment in hospitals. This study recommends that good healthcare-seeking behaviour health promotion programmes should be targeted at parents since they are stakeholders in the healthcare-seeking decision-making of adolescents.

KEYWORDS: Socio-environmental, Factors, Preferences, Treatment, Typhoid Fever 


\section{INTRODUCTION}

Typhoid fever also known as enteric fever is an acute febrile illness caused by Salmonella enterica serotype typhi. The causal organism of typhoid is a Gram-negative bacterium that infects specifically the intestinal tract of man and can also enter the blood circulation. Typhoid fever manifests clinically with the following symptoms; prolonged fever, headache, malaise, nausea, loss of appetite, constipation and diarrhoea. In rare or severe cases, typhoid presents with abdominal ache, intestinal puncture and neurological complications.

The disease is a communicable disease that can be transmitted from an infected person to a healthy person as long as the infected person excretes the organism Salmonella typhi in the faeces or urine (Parry, Hien, Doughan et al 2002; Keddy, Sooka, Smith et al 2016; Eba \& Bekele, 2019). Everyone is at risk of typhoid fever especially in endemic countries like Nigeria where poverty is widespread, potable water is unavailable and there are low levels of sanitation and waste disposal systems. (Kasuku, Bouland, Epumba, \& Biley 2017).

Typhoid fever disease is common among populations where poverty, overcrowding and unhygienic conditions are widespread and the disease is transmitted through the ingestion of food and water contaminated with faeces. (Polonsky, Martinez-Pino, Nackers, 2014; Kabwama, Bulage, Nsubuga, 2017). The disease was estimated to produce 17.8 million cases each year among low-and-middle-income countries of the world, of which 7.2 million cases were in Central and Western Africa (Antillón, Warren, Crawford, 2017; Adesegun, Adeyemi, Ehioghae, 2020). However, about 14.3 million cases were recorded in 2017, of which $12.1 \%$ (1.73 million) were from sub-Saharan Africa, namely Central, Eastern, Southern and Western Africa (GBDS, 2019). Although an outbreak has not been recorded in Nigeria in 2021, an outbreak of the disease in Harare City, Zimbabwe occurred in places with broken sewers, overcrowded apartments with limited access to sanitary facilities. When untreated, typhoid fever has a case fatality rate of 10\%-30\%. (Allen \& Honest, 2010; Davis, Chonzi, Masunda et al).

As the disease continues to cause morbidity and mortality globally and remains a major public health problem all over the globe, there is an increasing need to more effectively prevent outbreaks. The higher burden of the disease is in low-and middle-income tropical countries due to factors such as poverty, unhygienic sanitary practices, as well as poor access to potable/safe drinking water to effectively control the disease (Nguri, 2011).

Although there have been notable advances in science in combating infectious diseases, the prevalence, incidence and burden of typhoid fever have continued to be on the rise especially in low-and -middle-income countries in Africa. (Pach, Warren, Chang et al, 2016). Yet, a review of literature of studies regarding typhoid conducted in Ikenne LGA has demonstrated that there are generally low levels of knowledge regarding typhoid disease (Runsewe-Abiodun, Alabi, Bodunde et al, 2016).

Several studies have focused on sanitation or level of hygiene, food and water contamination. (Alba, Bakker, Hatta et al, 2016; Mogasale, Ramani, Lee et al 2016) confirmatory diagnosis, surveillance and treatment of clinical cases of the disease. But this present study is prompted by findings from some study conducted in Ogun State regarding typhoid fever. Studies such as that conducted by Adogo, Samuel \& Abalaka (2015) reported that the prevalence of typhoid among food handlers in Ogun State was 92.50\%. Similar research conducted in Abeokuta, 
South-western Nigeria, to determine the prevalence of Salmonella typhi among patients recorded a high prevalence of $80.1 \%$. (Okonko, Soleye, Eyarefe et al, 2010). Findings from these studies suggest that the disease is of public health significance in Ogun State.

Several factors have been identified by previous researchers as influencing care-seeking behaviour. And these factors include; socio-economic status, cultural beliefs and perceptions, ignorance, physical inaccessibility of health facilities, educational level, cost and quality of health, non-satisfaction with treatment (Shaikh \& Hatcher, 2005).

Other factors which have been observed to influence healthcare-seeking behaviour are; decision making by household members (parents) to seek medical care, social network and economic status. Other factors that have been observed by researchers to influence healthcareseeking behaviour include; inadequate resources, cultural taboos, availability of traditional care in the environment, no access to healthcare facilities, educational status, size of family, and perceived severity of illness (Onwujekwe, Uzochukwu, Eze et al., 2008; Pourreza, Khabiri, Foroushani et al., 2011; Adedokun, Morhason-Bello, Ojengbede et al., 2012)

Supporting the findings of previous researchers, (Mubyazi, Barongo, \& Kamugisha 2013) posits that health-seeking behaviour can be influenced by culturally-rooted knowledge and beliefs.

The objectives of this study were to determine the socio-environmental factors that influence care-seeking preferences for typhoid fever treatment among students of secondary schools in Ikenne LGA. This study hypothesized that there will be a significant relationship between socio-environmental factors and care-seeking preferences.

\section{MATERIALS AND METHODS}

Study design and population: The adopted study design was a cross-sectional survey design to assess the cognitive factors that influence care-seeking preferences for typhoid treatment among students of selected secondary schools in Ikenne Local Government Area of Ogun State. The chosen design was considered appropriate in examining the variables of this study.

Study Sample and Technique: the study participants comprised 422 students from selected Public Secondary Schools in Ikenne Local Government Area. A multi-stage sampling technique was used to determine the schools that participated in this study. Cluster sampling was used to separate the schools in the local government into clusters according to the different wards, then a balloting system was used to select the schools that participated in the study and one school was selected from each of the five wards that make up the local government. Proportionate sampling was used to determine the number of students from each of the selected schools to be enlisted in the study as well as the number of students from each class in the selected schools to be included in the study. Systematic sampling was used to determine how respondents were selected for the study; this was done by dividing the total population of students in the selected schools by the calculated sample size. Which was $\frac{50055005}{422422}=11.8$

which is approximately 12 . This, therefore, implies that every $12^{\text {th }}$ student in each class according to the teacher's register was selected. This study was approved by the Health Research Ethics Committee of the author's institution. 
Data Collection Method: a close-ended, self-administered questionnaire was used to acquire information for this study.

Data analysis: The data collected were coded and entered into the computer-assisted statistical software Statistical Package for Social Sciences (SPSS 25.0 version). Analysis of data was done at a $5 \%$ level of significance. The tools of frequency distribution, mean, and standard deviation were used for the summary. While multiple regression and correlation were employed in determining relationships between variables.

\section{RESULTS}

Socio-demographics Characteristics of Participants: The socio-demographic characteristics of respondents are shown in table 3.1. The respondents' ages ranged from 10-19 years with a mean of $15.3 \pm 1.7$ years. The ages of most $(68.1 \%)$ of the respondents fell within the $15-19$ years age range. More than half $(57.6 \%)$ of the respondents were female. A majority $(79.6 \%)$ of the respondents were adherents of the Christian faith. Above a quarter $(30.5 \%)$ of the respondents were in SS1. The respondents were predominantly Yoruba (77.5\%) while less than half $(48.7 \%)$ of the respondents' parents had secondary education.

Table 3.1 Socio-demographic Characteristics of the Respondents

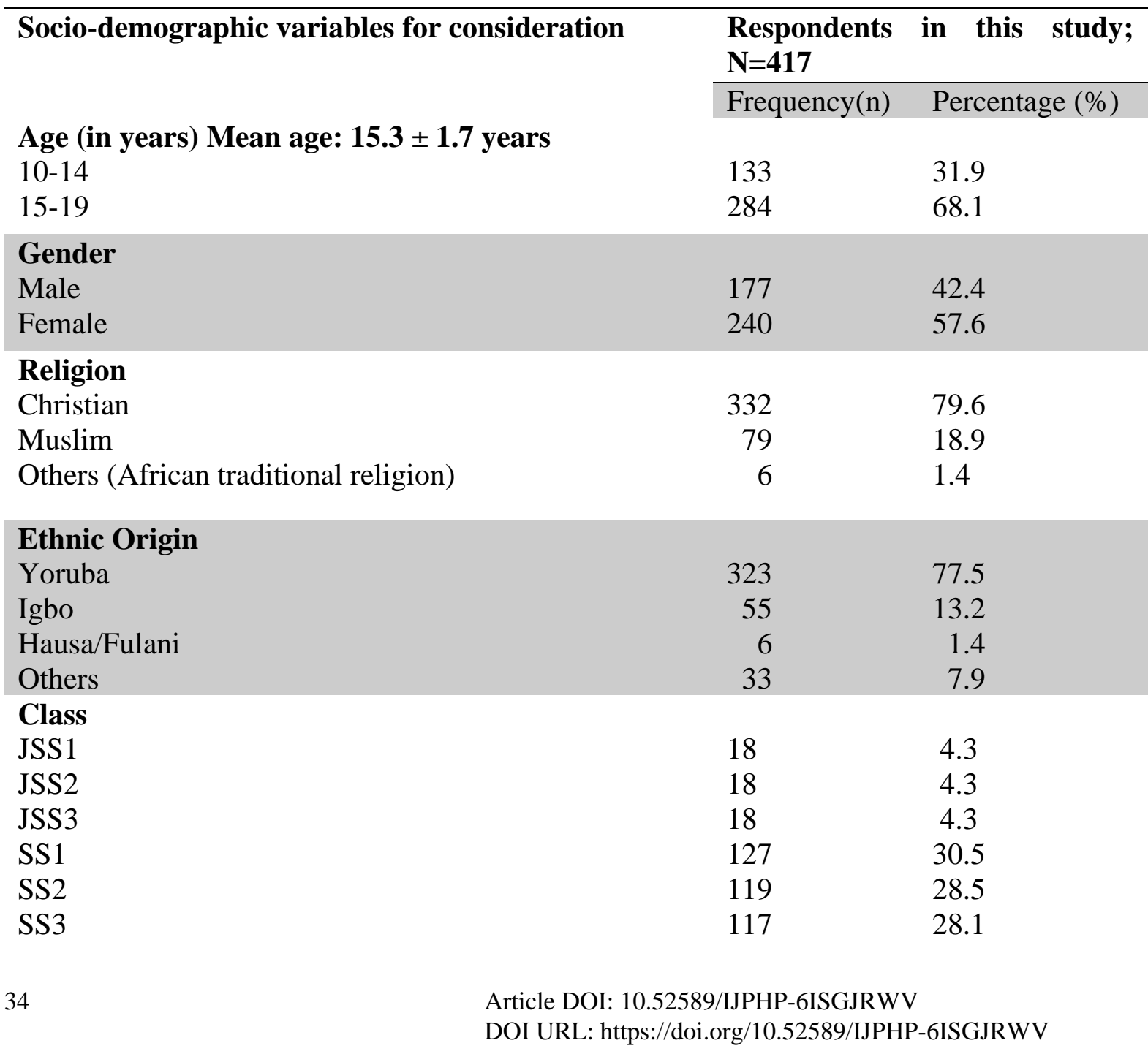




\begin{tabular}{lrl} 
Parent's educational Level & & \\
Primary & 25 & 6.0 \\
Secondary & 203 & 48.7 \\
Tertiary & 130 & 31.2 \\
Non-formal education & 59 & 14.1 \\
\hline
\end{tabular}

\section{Care-Seeking behaviour of Respondents}

Less than half $(47.0 \%)$ of the respondents had experienced typhoid fever. Over a quarter $(42.3 \%)$ of the respondents experienced typhoid fever over a year ago (See, figure 4.2). Of those who had experienced typhoid fever, less than half $(32.1 \%)$ received treatment in the hospital. Few (11.0\%) purchased drugs at the pharmacy while only $(3.8 \%)$ received traditional treatment (See, Table 3.2.1). The respondents' healthcare-seeking behaviour was measured on a 3-point rating scale. The mean score was $2.2 \pm 0.66$

Table 3.2.1 Respondents Care Seeking behaviour on Typhoid

\begin{tabular}{llc}
\hline Statement mean score was 2.2 \pm 0.66 & \multicolumn{2}{c}{ Respondents in this study N=417 } \\
\cline { 2 - 3 } & Yes $(\%)$ & No $(\%)$ \\
\hline $\begin{array}{l}\text { Have you ever had typhoid fever } \\
\begin{array}{l}\text { When you had typhoid where did you } \\
\text { receive treatment }\end{array}\end{array}$ & $196(47.0)$ & $221(53.0)$ \\
$\begin{array}{l}\text { Hospital } \\
\text { Traditional healer }\end{array}$ & $134(32.1)$ & $283(67.9)$ \\
Buy drug in the pharmacy & $16(3.8)$ & $401(96.2)$ \\
\hline
\end{tabular}

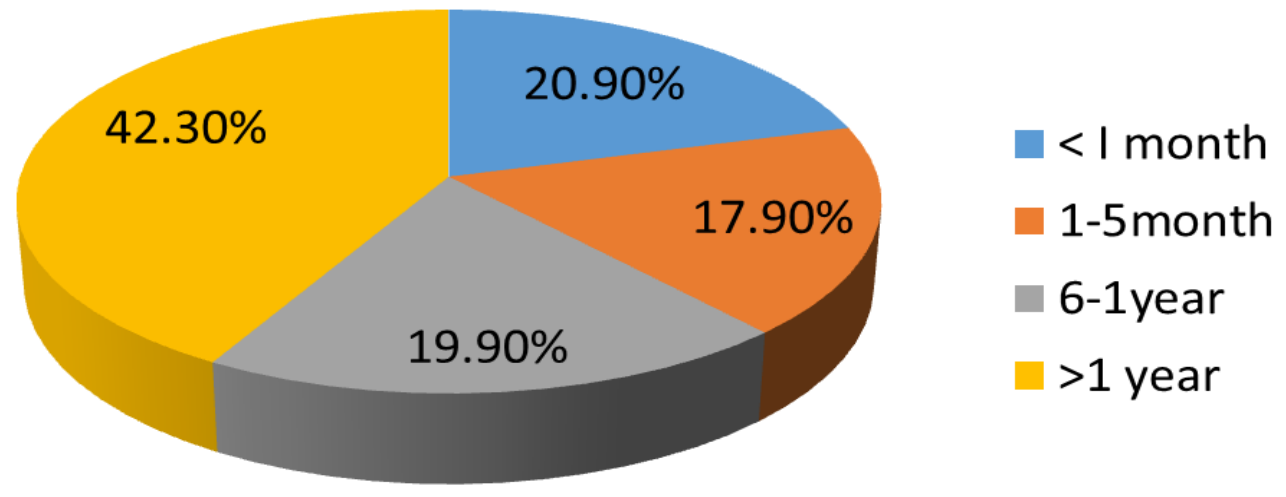

Figure 3.1: Proportion of Respondents who have had Typhoid Fever 


\section{Socio-Environmental Factors Affecting Care Seeking Preferences}

Less than half (43.4\%) of the respondents strongly agreed that their parents decide the type of treatment they receive when they are ill. Also, 198(47.5\%) of the respondents strongly agreed that the hospital where they receive healthcare is chosen by their parents.

Few $(16.1 \%)$ of the respondents strongly agreed that the high cost of healthcare prevents their parents from seeking medical care when ill with typhoid. Only (9.8\%) of the respondents strongly agreed that doctors were always too busy to attend to them when they visited the hospital.

Less than half $(37.6 \%)$ of the respondents strongly disagreed that health facilities are too far away from their place of residence (See, Table 3.3.1).

The respondent's socio-environmental factors were measured on a 15-point rating scale. The mean score was $10.32 \pm 2.53$.

Table 3.3.1. Socio-Environmental Factors that Influence Care Seeking behaviour of Respondents on Typhoid Fever

$\mathrm{N}=\mathbf{4 1 7}$

\begin{tabular}{lllll}
\hline $\begin{array}{l}\text { Statements } \\
\text { The mean score was 10.32 } \mathbf{2 . 5 3}\end{array}$ & $\begin{array}{l}\text { Strongly } \\
\text { agree } \\
\text { F (\%) }\end{array}$ & $\begin{array}{l}\text { Agree } \\
\text { F (\%) }\end{array}$ & $\begin{array}{l}\text { Dis } \\
\text { Agree } \\
\text { F (\%) }\end{array}$ & $\begin{array}{l}\text { Strongly } \\
\text { Disagree } \\
\text { F (\%) }\end{array}$ \\
\hline $\begin{array}{l}\text { My parents decide the type of treatment I } \\
\text { get when I am ill }\end{array}$ & $181(43.4)$ & $144(34.5)$ & $40(9.6)$ & $52(12.5)$ \\
$\begin{array}{l}\text { The hospital where I receive healthcare is } \\
\text { chosen by my parents }\end{array}$ & $198(47.5)$ & $167(40.0)$ & $32(7.7)$ & $20(4.8)$ \\
$\begin{array}{l}\text { The high cost of healthcare prevents my } \\
\text { parents from seeking medical care when ill } \\
\text { with typhoid }\end{array}$ & $67(16.1)$ & $87(20.9)$ & $115(27.5)$ & $148(35.5)$ \\
$\begin{array}{l}\text { The doctors are always too busy to attend } \\
\text { to me when I visit the hospital }\end{array}$ & $41(9.8)$ & $46(11.0)$ & $153(36.7)$ & $177(42.5)$ \\
$\begin{array}{l}\text { Health facilities are too far away from my } \\
\text { residence }\end{array}$ & $48(11.5)$ & $63(15.2)$ & $149(35.7)$ & $157(37.6)$ \\
\hline *Expected responses & & & & \\
\hline
\end{tabular}

\section{Test of Hypothesis}

A hypothesis was tested for this study to determine the influence of socio-environmental factors on care-seeking preferences for typhoid fever treatment. In testing this hypothesis, Pearson correlation and multiple regressions were conducted at a 0.05 level of significance. The decision rule applied was that if the $\mathrm{p}$-value computed was less or equal to the cut-off $\mathrm{p}$-value of 0.05 , the null hypothesis will be rejected in favour of the alternative hypothesis and viceversa.

$\mathrm{H}_{0}$ 1: There is no significant relationship between the respondent's socio-environmental factors and healthcare-seeking behaviour on typhoid. The result of the correlation showed a significant 
relationship between respondents healthcare-seeking behaviour on typhoid and respondents' parents' decision on the type of treatment for typhoid fever $(\mathrm{r}=-0.14 ; p=0.004)$. Also, there is a significant relationship between healthcare-seeking behaviour and the cost of healthcare $(\mathrm{r}=0.25 ; p=0.000)$ (See table 3.4.1). However, there is no significant relationship between choice of health care $(\mathrm{r}=0.05 ; p=0.30)$; the distance of the health facilities $(\mathrm{r}=0.02 ; \mathrm{p}=0.96)$ and healthcare-seeking behaviour. Furthermore, the multiple regression analysis showed that respondents' parents' decision to the type of treatment for typhoid fever contributes $6 \%$ to the respondents' healthcare-seeking behaviour $\left(\mathrm{R}=0.25 ; \mathrm{R}^{2}=0.06 ; \mathrm{p}<0.05\right)$, while the cost of healthcare contributes $7 \%$ to the respondent's health care seeking behaviour $\left(R=0.26 ; R^{2}=0.07\right.$; $\mathrm{p}<0.05$ ) (See table 3.4.2). Therefore, based on these values, the respondent's healthcareseeking behaviour is dependent on the parent's decision on the type of treatment for typhoid and the cost of treatment, but it is independent of the choice of health care facilities, the distance of health facilities. The overall result for correlation between socio-environmental factors and care-seeking preferences showed no significant relationship ( $\mathrm{r}=0.05 ; p=0.22$ ). Hence, the null hypothesis is accepted.

\section{Table 3.4.1: Relationship between Respondents' Socio-environmental factors and Health care-seeking Behaviour}

\begin{tabular}{llc}
\hline Variables: & \multicolumn{1}{c}{$\begin{array}{l}\text { Health } \\
\text { Behaviour } \mathbf{N}=\mathbf{4 1 7}\end{array}$} \\
\cline { 2 - 3 } & $\mathrm{R}$ & $\begin{array}{c}\text { care-Seeking } \\
\text { p-value }\end{array}$ \\
\hline $\begin{array}{l}\text { My parents decide the type of treatment I get when I am ill } \\
\begin{array}{l}\text { The hospital where I receive healthcare is chosen by my } \\
\text { parents }\end{array}\end{array}$ & -0.14 & $0.004^{*}$ \\
$\begin{array}{l}\text { The high cost of healthcare prevents my parents from seeking } \\
\text { medical care when ill with typhoid }\end{array}$ & 0.25 & 0.30 \\
$\begin{array}{l}\text { The doctors are always too busy to attend to me when I visit } \\
\text { the hospital }\end{array}$ & 0.025 & $0.000^{*}$ \\
$\begin{array}{l}\text { Health facilities are too far away from my residence } \\
\text { Socio-environmental factors }\end{array}$ & 0.02 & 0.96 \\
\hline
\end{tabular}

*Significant at $p<0.05$

Table 3.4.2 Association between Respondents Socio-Environmental factor and Health Care Seeking Behaviour

\begin{tabular}{|c|c|c|c|c|c|c|}
\hline \multirow[t]{3}{*}{ Vari } & \multicolumn{6}{|c|}{ Health Care Seeking Behaviour } \\
\hline & \multicolumn{6}{|c|}{ Respondents in this study; $\mathrm{N}=417$} \\
\hline & $\mathrm{R}$ & $\mathrm{R}$ square & $\mathrm{B}$ & Beta & $\mathrm{F}$ & p-value \\
\hline $\begin{array}{l}\text { Parents decide the type } \\
\text { of treatment }\end{array}$ & 0.25 & 0.06 & 0.15 & 0.25 & 27.68 & 0.000 \\
\hline $\begin{array}{l}\text { High cost of seeking } \\
\text { medical care }\end{array}$ & 0.29 & 0.08 & -0.06 & -0.99 & 5.91 & 0.000 \\
\hline
\end{tabular}




\section{DISCUSSION OF FINDINGS}

\section{Care Seeking Behaviour for Typhoid Fever}

The findings of this study showed that $47 \%$ of the respondents had suffered from typhoid fever one or more times in their lifetime. This is a clear indication that typhoid fever is prevalent among secondary school students. Further results of this study revealed that less than half $(32.1 \%)$ received treatment in the hospital. Few $(11.0 \%)$ purchased drugs at the pharmacy while only $(3.8 \%)$ received traditional treatment. This finding is not in line with the results of Nguri, (2011) in Kenya where 56.7\% of respondents sought professional medical care in the District Hospital in a suspected case of typhoid fever, $92 \%$ seek for treatment only after falling sick while $8.32 \%$ did not seek for any of treatment both traditionally or medically after they fell ill. Nanloh, Nanyak, and Dauda, (2015) reported that in Jos, the majority of the respondents preferred to self-medicate instead of seeking professional healthcare when they come down with a fever.

Also, a similar study conducted in Niger Delta University, Bayelsa State, Nigeria, reports that a larger proportion $(65.2 \%)$ of study participants sought professional medical care when they fall ill while the rest of the participants sought other means of treatment such as community pharmacy/patent medicine practitioner and traditional healing methods. (Ganiyu, Kpokiri, \& Dambo, 2017). Marie-Rosette, Candide, Olushayo, et al., (2017) reported that the majority of respondents $(96 \%)$, reported seeking medical care when sick with typhoid, with $95.8 \%$ of them seeking care from orthodox healthcare sources. The difference in the findings may be due to the difference in the study population. Additionally, the study revealed a relationship between respondent's perception of Typhoid fever and health-seeking behaviour. This is consistent with the reports of Adedokun et al., ( 2012) that perception of the severity of typhoid fever influences health-seeking behaviour.

\section{Socio-Environmental Factors Associated with Care Seeking Behaviour for Typhoid.}

This study revealed that the socio-environmental factor that influenced the respondents' healthseeking behaviour for Typhoid treatment was the decision of parents on the type of treatment they can receive as well as the cost of the treatment. This finding is similar to the findings of Onwujekwe, Uzochukwu, Eze et al., 2008; Pourreza, Khabiri, Foroushani et al., 2011; Adedokun, Morhason-Bello, Ojengbede et al., 2012. Similarly, Alonso and Little (2019), identified parents as important stakeholders in accessing healthcare for their adolescent children.

\section{CONCLUSION}

Typhoid is a communicable disease and the bacteria of typhoid survive in unhygienic conditions. The disease was estimated to produce 17.8 million cases each year among low-andmiddle-income countries of the world, of which 7.2 million cases were in Central and Western Africa (Antillion et al, 2017; Adesegun et al. 2020). As the disease continues to cause morbidity and mortality globally and remains a major public health problem all over the globe, there is an increasing need to more effectively prevent outbreaks. The higher burden of the disease is in low-and middle-income tropical countries due to factors such as poverty, unhygienic sanitary 
practices, as well as poor access to potable/safe drinking water to effectively control the disease (Nguri, 2011).

The socio-environmental factors that influence the respondents' health-seeking behaviour for typhoid fever were parents' decision on the type of treatment and the cost of the treatment.

\section{RECOMMENDATIONS}

This study has shown that parental influence is a significant determinant of care-seeking behaviour, therefore, this knowledge can help health program planners to target parents when developing health promotion programmes that promote good healthcare-seeking behaviour.

The study will also serve as a source of reference for further study on typhoid fever.

Lastly, the study will enrich existing literature in health promotion and prevention of infectious diseases.

\section{REFERENCES}

[1] Adedokun, B.O. Moharson-Bello, I.O. Ojengbede, O.A. Okonkwo, N.S.\& Kolade, C.(2012). Health-seeking Behaviour Among Women Currently Leaking Urine in Nigeria: Is it any different from the rest of the world? Patient Preference Adherence.6:815-819.

[2] Adesegun, O.A, Adeyemi, O.O,Ehioghae, O. Rabor, O.F. Binuyo, T.O. Alafin, B.A. Nagha, O.B. Idowu, A.O. \& Osunuga, A. (2020). Current Trends in the Epidemiology of Typhoid fever in Africa: A Literature Review. Asian Pacific Journal of Tropical Medicine. 13(5) 204-213.

[3] Adogo, I. Samuel, G. \& Abalaka, M. (2015). Sero-Prevalence of Salmonella typhi Among Pregnant Women in Niger State. Journal of Microbiology Research. 5:118-121

[4] Ahmad, S.A. Nuru, Y.U. Maimuna, Y.Y. \& Habu, C. (2013). Epidemiological Assessment of Knowledge and Risk Perception Towards Typhoid Fever Among GyadiGyadi- Communities in Kano, Nigeria. 2013 [Retrieved 13 ${ }^{\text {th }}$ February 2021 ] Available at https://doi.org/10.21522/TIJPH.2013.07.04.Art010.

[5] Alba, S. Bakke,r M.I. Hatta, M. Scheelbeek, P.F.D. Dwiyant, R. \& Usman, R.. (2016). Risk Factors of Typhoid Infection in The Indonesian Archipelago. Plus One.2016;11(6), e0155286.

[6] Allen, M \& Honest, N. (2010). Prevalence and Constraints of Typhoid Fever and its Control in an Endemic Area of Singida Region in Tanzania: Lessons for Effective Control of the Disease. Journal of Public Health Epidemiology. 2(5):93-99

[7] Alonso, J. \& Little, E. (2019). Parent Help-seeking Behaviour: Examining the Impact of Parents Beliefs on Professional help-seeking for Child Emotional and Behavioural Difficulties. The Educational and Developmental Psychologist, 36(2).

[8] Antillón, M. Warren, J.L. Crawford, F.W. Weinberger, D.M. Kürùm, E.\& Pak, G.D. (2017).The Burden of Typhoid Fever in Low-and Middle-Income Countries: A MetaRegression Approach. Plus Neglected Tropical Diseases. 11(2). 
[9] Bara, H.T. Makoni, A.C. Masunda, K.P.E. Vere, M. Makwara, I.P. Menyara, J. Mukeredzi, ., Moetsabi, T. \& Chonzi, P. (2016). Knowledge, Attitudes and Practices Related to Typhoid-the Case of Glen View Suburb, City of Harare. 2016. Available from https://www.coalitionagainsttyphoid.org.

[10] Davis, W.W. Chonzi, P. Masunda, K.P. \& Mukeredzi, I. (2018). Notes From The Field: Typhoid Fever Outbreak-Harare, Zimbabwe, October 2016-March 2017. MMWR Morbidity Mortality Weekly Report 2018;67:342-343.

[11] Dewan, A.M. Corner. Hashizume, M. \& Ongee, E.T. (2013). Typhoid Fever and its Association With Environmental Factors in the Dhaka Metropolitan Area of Bangladesh: A Spatial and Time-Series Approach. Plus Neglected Tropical Typhoid Diseases. 7(1), 1-14.

[12] Dinknesh, G. Betelhem, W. Wesene, E. Beletech, G. Workye, D. Sisay, W. \& Tadele, D. (2018). Assessment of Knowledge and Risk Perception towards Typhoid Fever among Communities in Mendida Town, Ethiopia. EC Paediatrics.7(12):1141-1157

[13] Eba, K. \& Bekele, D. (2019). Prevalence of Typhoid Fever and Its Risks Factors in Lalo Assabi District, West Wollega, Oromiya, Ethiopia. Journal of Bacteriology and Parasitology. 10:365.

[14] Ganiyu, K.A. Kpokiri, E.E. Dambo, T.W. (2017). Health Seeking Behavior and HealthRelated Quality of Life Among Students of Niger Delta University, Bayelsa State, Nigeria. African Journal of Pharmaceutical Research \& Development. 9(2):125-132.

[15] Getachew, D. Wale, B. Eshete, W. Getahun, B. Demise, W. Shewasinad, S. et al. (2018).Assessment of Knowledge and Risk Perception towards Typhoid Fever among Communities in Mendida Town, Ethiopia. EC Paediatrics. 7(12):1141-1157.

[16] GBDS. The Global Burden of Typhoid and Paratyphoid Fevers: A Systematic Analysis for The Global Burden of Disease Study 2019. Lancet Infectious Disease. 2019;19:369381.

[17] Kabwama, S.N. Bulage, I. Nsubuga, F. Pande, G. Oguttu, D.W. \& Mafiggiri, R. A. (2017). Large and Persistent Outbreak of Typhoid Fever Caused by Consuming Contaminated Water and Street-Vended Beverages: Kampala, Uganda, January-June, 2015. BMC Public Health. 17(23), 1-9.

[18] Kanj, S.S. Kanafani, Z.A. Shehab, M. Sidani, N. Baban, T. \& Baltajian, K. (2015). Epidemiology, Clinical Manifestations, and Molecular Typing of Salmonella typhi Isolated From Patients with Typhoid Fever in Lebanon. Journal of Epidemiology and Global Health. 5(2), 159-165.

[19] Kasuku, W. Bouland, C. Epumba, B. \& Biley, E. (2017).Typhoid Fever, a Public Health Problem in Hospitals: Case Study at Work Station in Kinshasha, DR Congo. $\mathrm{JOJ} \mathrm{Pb}$ Health 2(3): 555586.

[20] Keddy, K..H. Sooka, A. Smith, A.M. Musekiwa, A. Nomsa, P.T. Klugman, K.P \& Augulo, F.J. (2016). Typhoid Fever in South Africa in an Endemic HIV Setting. Plus One. 11(10), 1-12.

[21] Marie-Rosette, N. Candide, T.N. Olushayo, O. Jose, N. Ayodeji, I. Vedaste, N. Lakruwan, D. Andre, R. (2017). Pan African Medical Journal. 28:54.

[22] Mogasale, V. Ramani, E. Lee, J.S. Park, J.Y. Lee, K.S. (2016). Revising Typhoid Fever Surveillance in Low-and- Middle-Income Countries: Lesson From Systemic Literature Review of Population-Based Longitudinal Studies. BMC Infectious Diseases, 16(35), 112. 
[23] Mourad, A. Habumugisha, V. \& Sule, F.(2019). Assessing Students' knowledge of WASH-Related Diseases Settings. International Journal of Environmental Research and Public Health. 16(11).

[24] Mubyazi, G.M., Barongo, V.K \& Kamugisha M.L. (2013). Public Knowledge, Perceptions and Practices in Relation to Infectious and other Communicable Diseases in Tanzania: Lessons Learnt from Babati District, Rwanda. Journal of Health Sciences 2:112.

[25] Nahimana, M. Ngoc, C. Olu, O. Nyamusore, J. Isiaka, A.\& Ndahindwa, V. (2017). Knowledge, Attitude and Practice of Hygiene and Sanitation in a Burundian Refugee Camp: Implications for Control of a Salmonella typhi outbreak. Pan African Medical Journal. 2017;28.

[26] Nanloh, J.S. Nanyak, G.Z. \& Dauda, D.A. (2015). Assessment of the Knowledge and Attitude of Jos Residents Towards the Prevention and Treatment of Fever. Medical Journal of D.Y Patil Univ. 8:295-298.

[27] Nguri, K.A.B. (2011). Risk Factors Influencing Typhoid Fever Occurrence Among The Adults in Maina Slum, Nyahururu Municipality. Kenya [Doctoral Dissertation] Kenyetta University;2011.

[28] Ogah, J.O. Adekunle, O.C. \& Adegoke, A.A. (2015). Prevalence of Salmonellosis among Food Handlers and the Health Implications on the Food Consumers in Lagos State Nigeria. Journal of Medical Microbiology and Diagnosis. 4(2):187.

[29] Okonko, I. Soleye, F.A. Eyarefe, O.D. Amusan, T.A. Abubakar, M.J. Adeyi, A.O. Ojezele, M.O. \& Fadeyi, A.(2010). Prevalence of Salmonella typhi Among Patients in Abeokuta South-Western Nigeria. British Journal of Pharmacology and Toxicology. $1(1): 6-14$

[30] Onwujekwe, O., Uzochukwu, B., Eze, S., Obikeze, E., Okoli, C., Ochonma, O. (2008). Improving Equity in Malaria Treatment: Relationship of Socioeconomic Status with Health Seeking as well as Perceptions of ease of using the services of different providers for the treatment of malaria in Nigeria. Malaria Journal, 2008;7:5.

[31] Pach, A. Warren, M. Chang, I. Im, J. Nichols, C. \& Meyer, C.A.(2016). Qualitative Study Investigating Experiences, Perceptions and Healthcare System Performance in Relation to the Surveillance of Typhoid Fever in Madagascar. Clinical Infectious Diseases.62(1), S69-S75.

[32] Parry, C.M. Hien, T.T. Doughan, G. White, N.J. Farrar, J.J. (2002).Typhoid Fever. New England Journal of Medicine. 28;347(22):1770-82.

[33] Polonsky, J.A. Martinez-Pino, I. Nackers, F. Chonzi, P. Manangazira, P. Herp, M.V. (2014). Descriptive Epidemiology of Typhoid fever During an Epidemic in Harare, Zimbabwe, 2014. Plus One. 9(12), 1-16.

[34] Pourreza, A., Khabiri, R., Foroushani, A.R, Sari, A.A, Arab, M., Kavosi, Z. (2011). Healthcare-Seeking Behaviour in Tehran, Islamic Republic of Iran. World Applied Science Journal, 14:1190-7.

[35]Ravi, M. Mathew, M. Maryvarghese, M. (2017). A Study To Assess the Knowledge Regarding Typhoid Fever and its Prevention Among High School Students at Selected Schools in Mangaluru. American International Journal of Research in Humanities, Arts \& Social Sciences. 20,1,70-73.

[36] Runsewe-Abiodun, T.I. Alabi, A.D. Bodunde, O.T. Olowonyo, M.T. Adetunji, J.O. (2016). Perception and Practice of Food Hygiene and Safety among Youth and Women of Child-Bearing Age in Ikenne Local Government, Ogun State, South-West, Nigeria: A Qualitative Study. Nigerian Medical Practitioner. 78(1-2):20-25. 
[37]Shaikh, B.T \& Hatcher, J. (2005). Health Seeking Behavior and Health Service Utilization in Pakistan: Challenging the Policymakers. Journal of Public Health (Oxf). 27(1):49-54.

[38] Shukula, J.B. Goyal, A. Singh S. \& Chandra P. (2014). Effects of Habitat Characteristics on the Growth of Carrier Population Leading To Increased Spread of Typhoid Fever: A Model. Journal of Epidemiology and Global Health. 4(2), 107-114.

[39] Wain, J. Hendriksen, R.S. Mikoleit, M.L. Keddy, K.H. Ochiai, R.L. (2015). Typhoid Fever. Lancet. 385(9973), 1136-1145. https://doi.org/10.10.16/S0140-67(13)62708-7. 